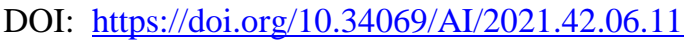
How to Cite:

Zhovkovska, T., Bezchasnyi, O., Usykova, O., Rybachuk, K., \& Dzhuryk, K. (2021). Predicting development based on a model of reflexive connections. Amazonia Investiga, 10(42), 113-123. https://doi.org/10.34069/AI/2021.42.06.11

\title{
Predicting development based on a model of reflexive connections
}

\section{Прогнозування розвитку на основі моделі рефлексивних зв'язків}

Received: May 5, 2021

\section{Abstract}

The purpose of the article is to develop an approach to quality forecasting of industrial enterprises. This article intends to understand how to take into account in predicting relationship, behavior and interaction of economic agents that affect the efficiency of the enterprise.

The result of the work is a reflexive approach to forecasting the development of an industrial enterprise, which focuses on prediction considering the complex interaction of economic agents in industrial activities as subjects of reflection with appropriate ranks. The approach based on the proposed model, which taking into account the reflective relationships between the industrial enterprise system and the components of the external environment, in which the industrial enterprise and other economic agents (or groups of economic agents) are considered as systems and trajectories. Depending on the trajectories of the components of the environment can be predicted development of industrial enterprises and management measures developed for correction. As components of the external
Accepted: June 13, 2021

\section{Аннотація}

Метою статті $є$ розробка підходу до якісого прогозування розвитку промислових підприємств.

Ця стаття має намір дати зрозуміти, як враховувати у прогнозуванні відносини, поведінку та взаємодії економічних агентів, що впливають на ефективність розвитку підприємства.

Результатом роботи $\epsilon$ представлений рефлексивний підхід до прогнозування розвитку промислового підприємства, який фокусується на прогнозуванні з урахуванням складної взаємодії економічних агентів у промисловій діяльності як суб'єктів рефлексії 3 відповідними рангами.

Підхід, заснований на запропонованій моделі, який враховує відображувальні взаємозв'язки між системою промислового підприємства та компонентами зовнішнього середовища, в якій промислове підприємство та інші економічні агенти (або групи економічних агентів) розглядаються як системи та траєкторії . Залежно від траєкторій руху компонентів середовища можна передбачити розвиток промислових підприємств та заходи

\footnotetext{
${ }^{47}$ Doctor of Economics Sciences, Western Ukrainian National University, Director of Chortkiv Vocational College of Economics and Entrepreneurship, Ternopil, Ukraine.

48 Doctor of Economics, Associate Professor, Associate Professor of the Department of Hospitality Industry and Sustainable Development, V.I. Vernadsky Taurida National University, Ukraine.

${ }^{49}$ Doctor of Economics Sciences, Associate Professor of Management Department, Director of the Educational Scientific Institute of Economics and Management, Mykolayiv National Agrarian University, Ukraine.

${ }^{50}$ Ph.D., Candidate of Pedagogical Sciences, Associate Professor, Head, Department of Organizational and Analytical Support of the State Supervision (Control), State Service for Education Quality of Ukraine, Kyiv, Ukraine.

${ }^{51}$ Lviv Polytechnic National University, postgraduate student of the Department of Finance, Lviv, Ukraine.
} 
environment, the trajectories of which must be taken into account when reflexively forecasting the development of an industrial enterprise are offered: the market of raw materials; groups of competitors; consumer groups; supplier groups; financial market; labor market. The model of taking into account the reflective connections between the system of the industrial enterprise and the components of the external environment is implemented in the PowerSim simulation package.

Keywords: development, reflexive, model, connections, prediction.

\section{Introduction}

Accurate forecasts are vital for decision support modern companies. The process of forecasting is the first step in the management of industrial establishments. When forecasting the development of enterprises traditionally refers to "identify and study possible alternatives for future development of the company" (Li et al, 2018) or "study of qualitative and quantitative changes its state in the future, as well as methods and deadlines to achieve these states" ( $\mathrm{Hu}$ et al, 2019). Forecasting provides grounds for the implementation of related management functions, first of all, further planning of the enterprise.

Usually in predicting the enterprise development is considered a major forecasting demand for products, so the most advanced forecasting methods are marketing component of the enterprise. But in today's world, under the conditions of the next industrial revolution and industrial transition in the sixth technological way, special attention needs forecasting and production technologies required for their development of human capital, etc. (Andriushchenko at el, 2019).

When forecasting the development of industrial enterprises should take into account that the company is a system, the results of which are very closely dependent on the environment. All economies are open and closed to some extent; and these systems include reflex subjects who have the ability to act differently (Zheng-Xin, 2013). First of all, the results of the industrial enterprise are influenced by the actions of its contractors - consumers, trade intermediaries, suppliers and so on. Thus, it is necessary to predict not only the probable trajectory of the industrial enterprise system, but also the trajectory of development of related systems, управління, розроблені для корекції. Як складові зовнішнього середовища, траєкторії яких необхідно враховувати при рефлексивному прогнозуванні розвитку промислового підприємства, пропонуються: ринок сировини; групи конкурентів; групи споживачів; групи постачальників; фінансовий ринок; ринок праці. Модель врахування відбивних зв'язків між системою промислового підприємства та компонентами зовнішнього середовища реалізована в симуляційному пакеті PowerSim.

Ключові слова: розвиток, рефлексивна, модель, зв'язки, прогнозування.

which is proposed to implement through a reflective approach, while analyzing the perception of the industrial enterprise by its counterparties and whether it adequately evaluates this perception.

This paper presents a reflexive approach to forecasting the development of industrial enterprises, able to evaluate and optimize the implementation of tasks. The main idea of the study is that by using reflective approach to forecasting the development of industrial enterprises is the ability to affect the interaction of economic agents in the implementation of the tasks of development and changes that have been caused by them, which allows for significantly reduced time to consider their response subjective component.

\section{Theoretical Framework or Literature Review}

In a general sense reflexive management includes the following components: awareness of self-interest entity management; installation of the control object; determination of their interest in relation to the object of management; definition contractors in confrontational relations; interaction with counterparties and providing them with grounds for decisionmaking (Dligach, 2016).

In the context of reflexive approach to forecasting the development of industrial enterprises offered distinguish the company that is both subject and object of management, and its contractors, who in the first rank reflection act as subjects, but may also be considered as subjects when using reflexive models of higher ranks.

In a general sense, ranked reflection (Robert \& Ola, 2020; Wang et al, 2020; Soros, 2013) 


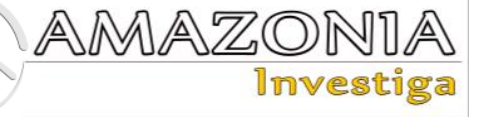

implies that the subject of reflection with the rank $\mathrm{K}$ takes its contractors as subjects of reflection with rank K-1 (Kuzior et al, 2021). When forecasting the development of enterprises in most situations it makes sense to consider industrial enterprise in terms of the first rank reflection and only a few cases in terms of the second rank. The first rank of reflection means that the industrial enterprise believes that its counterparties make decisions without taking into account its actions, ie have a reflection of zero rank. Zero-rank reflection is common in typical game theory models, where the subject decides on his strategy only from information about the payment matrix, without taking into account the strategies of other participants. In turn, if the company uses the second rank of reflection in forecasting trajectory, counterparties have the first rank, ie take into account the existence of this company, but do not take into account its reflective calculations. The general scheme of forecasting the development of an industrial enterprise taking into account the reflexive assessment of the actions of contractors are shown in Figure 1.

Thus are three main groups of objects that form the environment of an industrial enterprise, competitors, customers and suppliers, sales agents and more.

In reflection industrial enterprises rank zero (no reflection) forecasting carried excluding external environment is shown in Figure 1a.

Industrial enterprise carries forecasting key metrics based on previous periods, by simple extrapolation and continuation of the trend that is already there (Marinenko, 2016; Fildes \& Goodwin, 2020; Tarasova et al, 2019). The peculiarity of this prediction is the need to have enough observations to build trends indicators predicted (Wang \& Tan, 2021; Kang et al, 2021; Gonçalvesa et al, 2021; Nguyen et al., 2021; Hong, etc., 2021; Amendola et al, 2020; Kwilinski et al., 2019).

Thus are three main groups of objects that form the environment of an industrial enterprise, competitors, customers and suppliers, sales agents and more.

In reflection industrial enterprises rank zero (no reflection) forecasting carried excluding external environment is shown in Figure 1a.

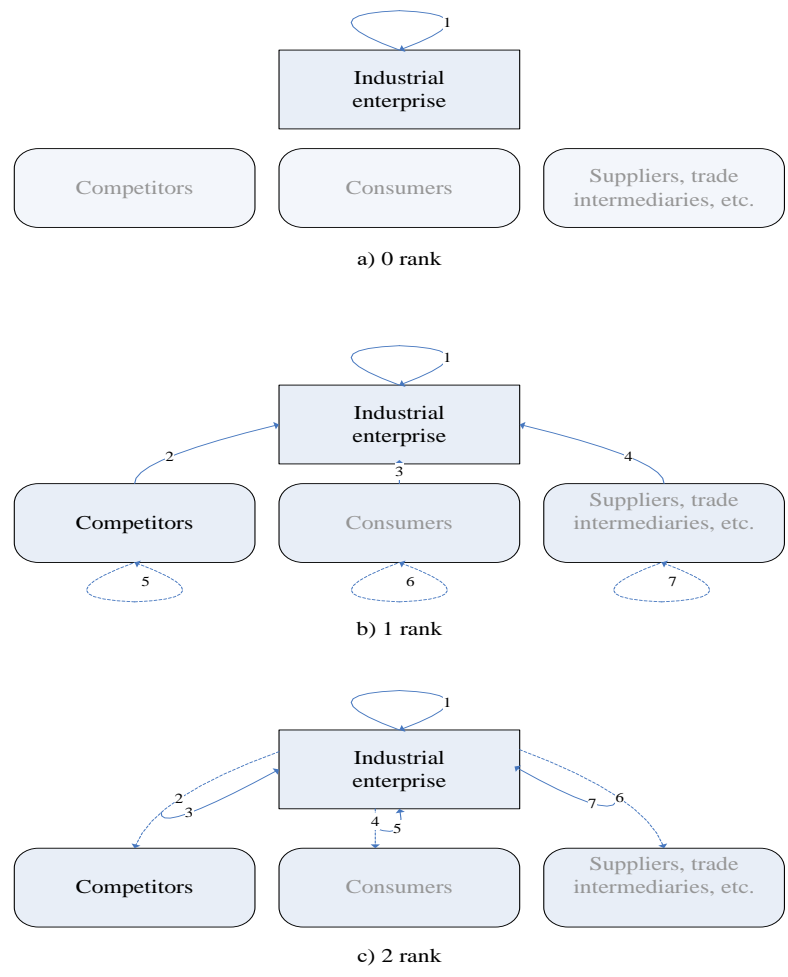

Figure 1. Reflexive construction of forecasts of the external environment of the enterprise.

Source: own research.

Industrial enterprise carries forecasting key metrics based on previous periods, by simple extrapolation and continuation of the trend that is already there. The peculiarity of this prediction is the need to have enough observations to build trends indicators predicted (Patomäki, 2017). 
This significantly limits the possibility of such forecasting, in addition, accuracy of forecasts will be sufficient only in a stable economy, without the emergence of disturbing factors, which is almost impossible in the modern world.

The main indicator that can be predicted at zero rank of reflection is the volume of sales.

At zero reflection appropriate to use such methods of forecasting:

time series analysis of the company's sales volume and its extrapolation into the future; time series analysis of the market products and calculate sales company as a share of the total market value based on the previous period.

In fact, this forecast does not take into account the response of other economic entities, the possibility of their significant positive or negative impact on the development of industrial enterprises.

More effective is forecasting the development of the company, when industrial enterprises forecasting exercise using the reflection of the first rank is shown in Figure 1b.

The following prerequisites are used:

other economic agents who have an influence on the industrial enterprise, carry out actions with zero rank of reflection; industrial enterprise recognizes and considers the existence of intentional influence on the activity of other economic agents.

economic agents who have an influence on the industrial enterprise, carry out actions with zero rank of reflection; industrial enterprise recognizes and considers the existence of intentional influence on the activity of other economic agents.

At the same time, it is possible to forecast a wider range of indicators of industrial enterprise development and related indicators than in the previous case.

Such indicators include:

sales volume by types of products;

product profitability;

market value of the enterprise;

market share of the enterprise;

comparative efficiency of production

technologies;

product competitiveness; comparative brand statement, etc.

Some of these indicators can have a basic projections based on the use of methods inherent to rank zero reflection, but most of them require consideration of predicting the actions of other economic agents. Thus, many industrial technologies and types of products are characterized by cyclicality, when every few years or decades there are updates and those companies that have not had time to modernize, go bankrupt.

These cycles are characterized as traditional industries such as automobile manufacturing and modern types of industrial production, such as production of electronic devices. In this case, it is necessary to use cyclical forecasting models that take into account both global economic cycles and local technological, demographic, consumer and other cycles.

Correlation and regression analyzes are effective for predicting the development of an industrial enterprise with reflection of the first rank. They reveal the relationship between factors that primarily influences between economic agents and indicators of industrial enterprises.

The forecasting is carried out in two stages.

First, the indicators of economic agents who have zero rank of reflection are predicted by analyzing time series and extrapolating them to the future.

In the second stage, the effects of these agents on the activities of the industrial enterprise are calculated, and then indicators of its development are forecast.

Thus, forecasting the development of an industrial enterprise using the reflection of the first rank provides a fairly accurate reflection of the effects of the external environment and at the same time does not require the use of too complex and expensive methods of studying this environment.

A more accurate, but also more difficult is predicting the development of industrial enterprises using reflection of the second rank is shown in Figure 1c. It is assumed that other economic agents reflection of the first rank, ie, take into account the actions of industrial enterprises and adapt to them. In turn, forecasts industrial enterprises are built taking into account these possible actions of other economic agents. 


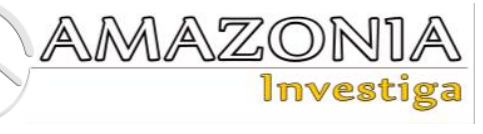

For this case it is appropriate to use simulation, especially methods scenario projections. The most appropriate solution to the problem of forecasting the development of industrial enterprises with regard reflexive actions of other economic agents such groups are methods for constructing scenarios of:

final consumption research;

trial marketing;

structural analysis of the competitive environment;

construction of a tree of situations on the basis of expert assessments;

Forecasting with the help of final consumption research is carried out by studying the consumers of the enterprise's products and determining their needs, including taking into account their development and possible replacement by competitors' products and substitute goods. Test marketing is effective study prospects of new or improved products. At the same time, test sales are carried out in a limited region or for a limited number of consumers and their reactions are investigated.

Structural analysis of the competitive environment is a well-known research method, which was proposed by M. Porter (1987). The following indicators are evaluated to assess the development of threats in the industrial sector: threats of new competitors, opportunities for consumers to put pressure on the manufacturer to reduce prices, opportunities for suppliers to put pressure on the manufacturer to increase prices, the likelihood of substitute goods, the degree of competition in the industry.

\section{Methodology}

Building a tree of situations based on expert assessments is carried out by interviewing heads of departments of the enterprise, sales agents, contractors and consumers, and other experts who have sufficient information and qualifications to predict the possible development of the external environment of the industrial enterprise. As a result of aggregating these surveys, a scenario tree can be constructed that reflects possible directions for change in the external environment. All of these methods and their combinations make it possible to resolve the problem of forecasting the development of the industrial enterprise - predicting the environment, taking into account both the reflective behavior of industrial enterprises and other economic agents.
This industrial enterprises and other economic agents (or group of economic agents) should be considered as a system with position and trajectory. Depending on the trajectories of the components of the environment can be predicted development of industrial enterprises and management measures developed for its correction. As components of the external environment, the trajectories that must be taken into account in the system-reflexive forecasting of the development of an industrial enterprise:

raw materials market;

groups of competitors;

consumer groups;

supplier groups;

financial market;

labor market.

Such components as competing groups of customers or suppliers can be represented as a number of groups for each component if they have fundamental differences that affect the development of the company and in general. For example, providers can be divided into two groups - which have a monopoly position and may exercise price pressures in industry, and all others. The trajectories of the components of the environment influence the trajectory of industrial enterprises, this relationship can be described as a simulation model.

The model of reflexive forecasting of industrial enterprise development taking into account reflexive connections between the system of industrial enterprise and components of external environment has the following look:

$S_{t}^{E}=S\left(D_{t}^{E}\right)$

$D_{t}^{E}=\left\{d_{t}^{E 1}, d_{t}^{E 2}, d_{t}^{E 3}, d_{t}^{E 4}, d_{t}^{E 5}, d_{t}^{E 6}, d_{t}^{E 7}\right\}$,

where $S_{t}^{E}$ - forecast of industrial enterprise development at the time $t$;

$D_{t}^{E}$ - the set of states of the industrial enterprise system at the time $t$ (selected only those indicators of the state that reflect the development of the enterprise);

$d_{t}^{E 1}$ - sales volume by type of product at the time $t$;

$d_{t}^{E 2}$ - product profitability at the time $t$;

$d_{t}^{E 3}-$ market value of the enterprise at the time 
$d_{t}^{E 4}-$ the company's market share at the time $t$; $d_{t}^{E 5}$ - comparative efficiency of production technologies at the time $t$;

$d_{t}^{E 6}$ - product competitiveness at the time $t$;

$d_{t}^{E 7}$ - comparative statement of the brand at the time $t$.

The specific function that converts many states of the industrial enterprise system into the initial value of development assessment depends on what the owners or managers of the enterprise consider to be development - it can be the improvement of all indicators, achieving set values or one aggregated multiplier. But the establishment of a specific indicator of development is a task for the planning stage, and for the stage of forecasting development the main task is to forecast the state of the system, which consists of its trajectory.

In turn, the trajectory of the system of an industrial enterprise depends on the trajectories of the components of the external environment:

$$
\begin{aligned}
& d_{t}^{E 1}=f^{E 1}\left(W_{t}^{2}, W_{t}^{3}\right), \\
& d_{t}^{E 2}=f^{E 2}\left(W_{t}^{1}, W_{t}^{2}, W_{t}^{3}, W_{t}^{4}, W_{t}^{5}, W_{t}^{6}\right), \\
& d_{t}^{E 3}=f^{E 3}\left(W_{t}^{2}\right), \\
& d_{t}^{E 4}=f^{E 4}\left(W_{t}^{1}, W_{t}^{2}, W_{t}^{3}, W_{t}^{4}, W_{t}^{5}, W_{t}^{6}\right), \\
& d_{t}^{E 5}=f^{E 5}\left(W_{t}^{2}, W_{t}^{3}\right), \quad(6) \\
& d_{t}^{E 6}=f^{E 6}\left(W_{t}^{1}, W_{t}^{2}, W_{t}^{4}\right), \\
& d_{t}^{E 7}=f^{E 7}\left(W_{t}^{2}, W_{t}^{3}\right), \quad(8)
\end{aligned}
$$

where $f^{E 1} \ldots f^{E 7}$ - functions that link the development of the industrial enterprise system with the systems of the external environment;

$W_{t}^{l}$ - forecast of raw material market development at the time $t$;

$W_{t}^{2}$ - forecast of competitors' development at the time $t$;
$W_{t}^{3}$ - consumer development forecast at the time $t$;

$W_{t}^{4}$ - forecast of supplier development at the time $t$;

$W_{t}^{5}$ - forecast of financial market development at the time $t$;

$W_{t}^{6}$ - forecast of labor market development at the time $t$.

Accordingly, each of the components of the external environment has the appropriate indicators, and in forecasting, these indicators may reflexively depend on the actions of the industrial enterprise:

$$
\begin{aligned}
& W_{t}^{1}=\left\{w_{t}^{1,1}, w_{t}^{1,2}, r^{1}\left(D_{t}^{E}\right)\right\}, \quad(9) \\
& W_{t}^{2}=\left\{w_{t}^{2,1}, w_{t}^{2,2}, w_{t}^{2,3}, r^{2}\left(D_{t}^{E}\right)\right\}, \\
& W_{t}^{3}=\left\{w_{t}^{3,1}, w_{t}^{3,2}, w_{t}^{3,3}, r^{3}\left(D_{t}^{E}\right)\right\}, \\
& W_{t}^{4}=\left\{w_{t}^{4,1}, w_{t}^{4,2}, r^{4}\left(D_{t}^{E}\right)\right\}, \quad(12 \\
& W_{t}^{5}=\left\{w_{t}^{5,1}, w_{t}^{5,2}, r^{5}\left(D_{t}^{E}\right)\right\}, \quad(13 \\
& W_{t}^{6}=\left\{w_{t}^{6,1}, w_{t}^{6,2}, w_{t}^{6,3}, r^{5}\left(D_{t}^{E}\right)\right\},
\end{aligned}
$$

where $w_{t}^{1,1}$-raw material prices at the time $t$; $w_{t}^{1,2}$ - quality of raw materials at the time $t$; $w_{t}^{2,1}$ - number of competitors at a time $t$; $w_{t}^{2,2}$ - sales of competitors at the time $t$; $w_{t}^{2,3}$ - comparative efficiency of competitors at the time $t$;

$w_{t}^{3,1}$ - market capacity at the time $t$;

$w_{t}^{3,2}$-availability of foreign markets at the time $t$;

$w_{t}^{3,3}$ - the tendency of consumers to change preferences at a time $t$;

$w_{t}^{4,1}$ - variety of suppliers at a time $t$;

$w_{t}^{4,2}$ - the quality of performance by suppliers of their contracts at the time $t$; 


\section{AMAZONIA \\ Dnvestiga}

$w_{t}^{5,1}-$ the cost of raising funds at the time $t$;

$w_{t}^{5,2}$ - ease of raising funds at a time $t$;

$w_{t}^{6,1}-$ the cost of labor at the time $t$;

$w_{t}^{6,2}$ - qualification of the workforce at the time $t$

$w_{t}^{6,3}$ - availability of labor at the time $t$

$r^{1} \ldots r^{6}-$ functions that reflect the

consideration of economic agents of the actions of the industrial enterprise in the reflection of the first rank.

Forecasts of development or trajectories of components of the external environment provide an opportunity to justify the existing limitations of the possibility of enterprise development. So if the whole market of raw materials has a positive trajectory, the company can develop towards cost reduction and if negative trajectory - that development can be considered even maintaining the current cost.

A positive trajectory is considered if all components of the system under study have a positive dynamics, and vice versa, if all indicators deteriorate, the trajectory can be considered negative.

In the case of different dynamics of indicators, the trajectory can be considered mixed, or to assess by calculating a single integrated indicator.

\section{Results and Discussion}

Implementation of the model taking into account the reflexive link between the industrial companies and environmental components in a package made of simulation PowerSim is shown in Figure 2.

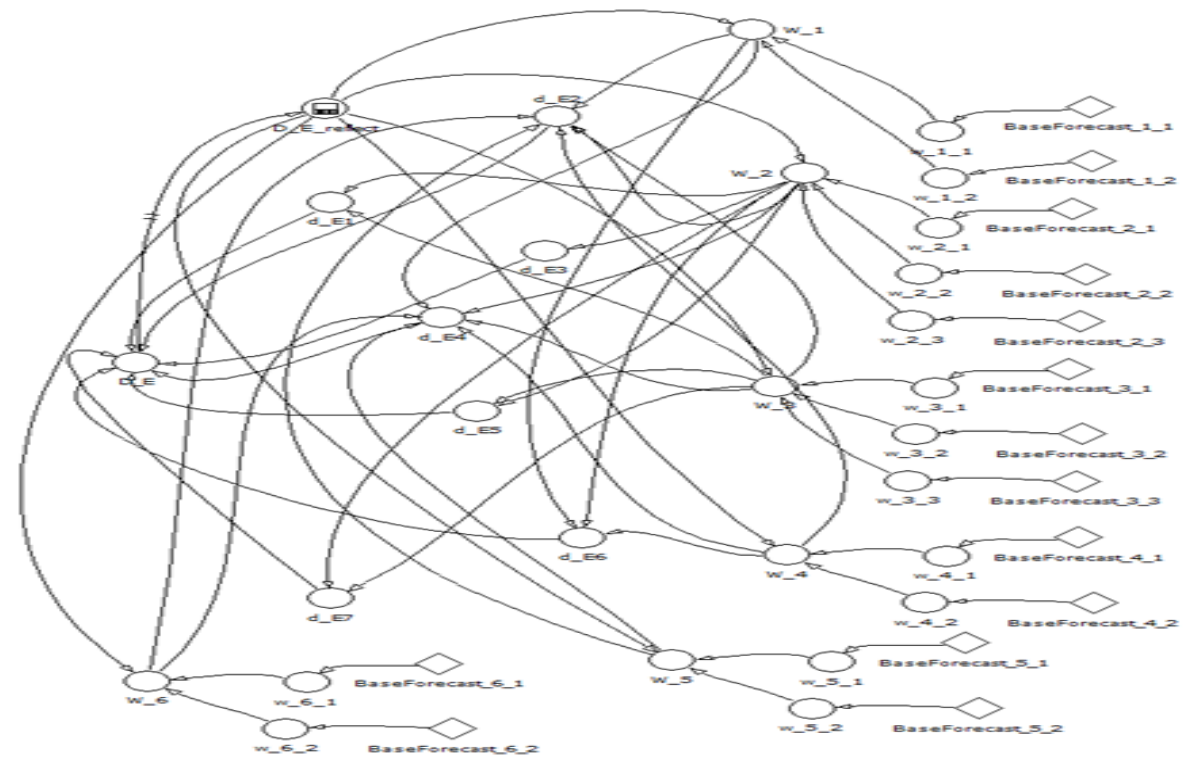

Figure 2. Simulation model accounting reflexive link between the industrial companies and environmental components implemented in the package PowerSim.

Source: own research

Approbation of the reflexive approach to forecasting the development of an industrial enterprise was carried out at the machinebuilding enterprises of Ukraine $\mathbf{A}$ and $\mathbf{B}$., which produce industrial equipment.

Enterprise $\mathbf{A}$ is a manufacturer of thermal equipment, primarily electric and gas furnaces, as well as other related industrial equipment. The peculiarity of the company, which distinguishes it from most competitors is the presence developed its own design department, which provides customized thermal design equipment according to customer needs.Overall activity A company can be considered a successful return on sales ranged from $28.3 \%$ to $50.3 \%$ and unprofitable in the past five years there was only one in 2019 is shown in Table 1.

Table 1.

Performance indicators of enterprise A, thousand USD 


\begin{tabular}{llllll}
\hline Indicator & 2016 & 2017 & 2018 & 2019 & 2020 \\
\hline $\begin{array}{l}\text { Net income from sales of products (goods, works, } \\
\text { services) }\end{array}$ & 56015 & 104040 & 51115 & 21511 & 69646 \\
Cost of goods sold (goods, works, services) & 37264 & 69393 & 38229 & 16626 & 54267 \\
Profitability of sales & $50,3 \%$ & $49,9 \%$ & $33,7 \%$ & $29,4 \%$ & $28,3 \%$ \\
Net financial result & 8876 & 18841 & 3402 & -5297 & 6263 \\
\hline
\end{tabular}

Source: own research

Using the proposed reflexive approach to forecasting the development of industrial enterprise, the forecasting of the external environment for enterprise A for 2021 was carried out. At the same time, the IMF's macroeconomic forecasts were used as baseline.
As a result of forecasting, it is established that most components of the environmental system will have negative dynamics, but provided that the advantages of those components of the environment have positive dynamics and effective adaptation to negative trajectories, company A will be able to provide overall positive results are shown in Table 2.

Table 2.

Forecasts of trajectories of states of systems of external environment of the enterprise $\boldsymbol{A}$

\begin{tabular}{|c|c|c|c|}
\hline $\begin{array}{l}\text { Environmental } \\
\text { systems }\end{array}$ & Forecast & Environmental indicators & Forecast \\
\hline \multirow{2}{*}{ Raw materials market } & \multirow{3}{*}{$\begin{array}{l}\text { without } \\
\text { significant } \\
\text { changes }\end{array}$} & raw material prices & $+10 \%$ \\
\hline & & quality of raw materials & unchanged \\
\hline \multirow{4}{*}{ Competitors } & & number of competitors & unchanged \\
\hline & \multirow[t]{3}{*}{ unchanged } & sales of competitors & unchanged \\
\hline & & comparative efficiency of competitors & unchanged \\
\hline & & market capacity & $+25 \%$ \\
\hline \multirow[t]{2}{*}{ Consumers } & \multirow[t]{2}{*}{ positive } & availability of foreign markets & $+10 \%$ \\
\hline & & $\begin{array}{l}\text { consumer propensity to change preferences } \\
\text { variety of suppliers }\end{array}$ & $\begin{array}{l}\text { unchanged } \\
\text { will get worse }\end{array}$ \\
\hline Suppliers & negative & $\begin{array}{l}\text { the quality of performance by suppliers of their } \\
\text { contracts }\end{array}$ & will get worse \\
\hline \multirow[t]{2}{*}{ Finance market } & \multirow[t]{2}{*}{ negative } & $\begin{array}{l}\text { the cost of raising funds } \\
\text { ease of raising funds }\end{array}$ & $\begin{array}{l}+40 \% \\
\text { unchanged }\end{array}$ \\
\hline & & labor costs & $+50 \%$ \\
\hline \multirow[t]{2}{*}{ Labor market } & \multirow[t]{2}{*}{ negative } & skills of the workforce & will get worse \\
\hline & & labor availability & will get worse \\
\hline
\end{tabular}

Source: own research

Thus, the negative prognoses of suppliers, finance and labor. The deterioration of the environment in terms of suppliers due to get away from the market some suppliers of materials.

Also, due to exchange rate fluctuations there are risks of non-performance or late performance of contracts for the supply of imported components. In the financial market, negative trends are expected due to the rising cost of borrowed funds.

The most difficult is the situation on the labor market. Further decline in skills and labor availability is expected due to emigration of workers to the EU and aging of skilled workers. As a result of raising the minimum wage and lack of qualified staff projected rise in the cost of labor.

But due to capacity growth markets, including the availability of foreign markets through further EU action Association, the aforementioned negative effects can be overcome.

It is necessary to plan appropriate measures to:

supply diversification to reduce negative trends in the supplier system;

increasing the accuracy of resource requirements planning to minimize the need to attract working capital;

training and education of skilled labor; 


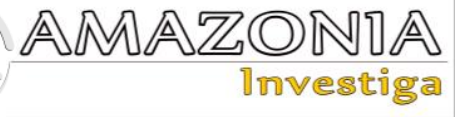

intensify the preparation of proposals to expand accessibility in the markets.

Enterprise B manufactures lifting and handling equipment, as well as building metal structures and parts of structures. The main consumers of products are enterprises of metallurgical and coke industries.

Mainly the products of enterprise $\mathbf{B}$ are used by Ukrainian industrial enterprises. According to

Table 3.

Performance indicators of enterprise $\boldsymbol{B}$, thousand USD

\begin{tabular}{llllll}
\hline Indicator & 2016 & 2017 & 2018 & 2019 & 2020 \\
\hline $\begin{array}{l}\text { Net income from sales of products } \\
\text { (goods, works, services) }\end{array}$ & 152133 & 125976 & 75173 & 128272 & 134241 \\
Cost of goods sold (goods, works, services) & 135511 & 117331 & 69774 & 109681 & 100550 \\
Profitability of sales & $12,3 \%$ & $7,4 \%$ & $7,7 \%$ & $17,0 \%$ & $33,5 \%$ \\
\hline Net financial result & 10520 & -7796 & -4171 & 267 & 47 \\
\hline
\end{tabular}

Source: own research

Prediction of the environment for the company $\mathbf{B}$ in 2021, carried out using the developed approach made it possible to establish that the the results of 2020, the share of products sold on the domestic market amounted to $62.03 \%$, while $37.97 \%$ of products were exported.

The effectiveness of the company $\mathbf{B}$ is unstable. Despite the relatively high rates of return on sales, which reached $33.5 \%$, net financial results unstable. In 2017-2018, the company had significant losses are shown in Table 3.

Table 4.

Forecasts of trajectories of states of systems of external environment of the enterprise $\boldsymbol{B}$

\begin{tabular}{|c|c|c|c|}
\hline $\begin{array}{l}\text { Environmental } \\
\text { systems }\end{array}$ & Forecast & Environmental indicators & Forecast \\
\hline $\begin{array}{l}\text { Raw materials } \\
\text { market }\end{array}$ & negative & $\begin{array}{l}\text { raw material prices } \\
\text { quality of raw materials } \\
\text { number of competitors }\end{array}$ & $\begin{array}{l}+35 \% \\
\text { unchanged } \\
\text { increase }\end{array}$ \\
\hline Competitors & negative & $\begin{array}{l}\text { sales of competitors } \\
\text { comparative efficiency of competitors } \\
\text { market capacity }\end{array}$ & $\begin{array}{l}\text { unchanged } \\
\text { high } \\
+20 \%\end{array}$ \\
\hline Consumers & positive & $\begin{array}{l}\text { availability of foreign markets } \\
\text { consumer propensity to change preferences } \\
\text { variety of suppliers }\end{array}$ & $\begin{array}{l}\text { will get worse } \\
\text { unchanged } \\
\text { unchanged }\end{array}$ \\
\hline Suppliers & positive & $\begin{array}{l}\text { the quality of performance by suppliers of their } \\
\text { contracts }\end{array}$ & \\
\hline Finance market & negative & $\begin{array}{l}\text { the cost of raising funds } \\
\text { ease of raising funds } \\
\text { labor costs }\end{array}$ & $\begin{array}{l}+40 \% \\
\text { unchanged } \\
+50 \%\end{array}$ \\
\hline Labor market & negative & $\begin{array}{l}\text { skills of the workforce } \\
\text { labor availability }\end{array}$ & $\begin{array}{l}\text { will get worse } \\
\text { will get worse }\end{array}$ \\
\hline
\end{tabular}

Source: own research

For both company $\mathrm{A}$ and company $\mathrm{B}$, the forecasts of the financial market and the labor market are negative. This is a common branch, respectively, indicators of these markets are also common. At the same time, the forecasts for consumers and suppliers are positive. Further exit of the metallurgical industry from the crisis will lead to improved performance of their contracts by suppliers. In addition, the demand majority of environmental trends are negative are shown in Table 4. 
is also expected to increase the activity of competitors who did not operate due to the crisis.

For enterprise development in, subject to the implementation of these projections need to plan the following activities:

diversification of suppliers in order to choose the most favorable prices;

modernization of technologies used at the enterprise in order to ensure sufficient competitiveness;

increasing the accuracy of resource requirements planning to minimize the need to attract working capital;

training and education of skilled labor.

\section{Conclusions}

In this paper presents a reflexive approach to forecasting the development of an industrial enterprise, which focuses on prediction considering the complex interaction of economic agents in industrial activities as subjects of reflection with appropriate ranks. It is proved that in predicting the development of the company in most cases it makes sense to consider industrial enterprise in terms of the first rank reflection and only a few cases in terms of the second rank.

The approach based on the proposed model, which taking into account the reflective relationships between the industrial enterprise system and the components of the external environment, in which the industrial enterprise and other economic agents (or groups of economic agents) are considered as systems and trajectories. Depending on the trajectories of the components of the environment can be predicted development of industrial enterprises and management measures developed for correction.

As components of the external environment, the trajectories of which must be taken into account when reflexively forecasting the development of an industrial enterprise are offered: the market of raw materials; groups of competitors; consumer groups; supplier groups; financial market; labor market.

Modeling consideration reflexive link between the industrial companies and environmental components showed well. The model of taking into account the reflective connections between the system of the industrial enterprise and the components of the external environment is implemented in the PowerSim simulation package. The model variant is adapted to real practical conditions. Designed reflective approach to forecasting the development of industrial enterprise tested on real data of major industrial facilities.

Evaluation of prediction accuracy using different criteria led to the conclusion that the approach makes it possible to develop forecasts that take into account impacts on the reflexive interaction of economic agents. Sectoral approach has features versatility and can be used for any industrial company.

Further development of the proposed approach would be to clarify and expand models predicting response contractors for the implementation of the tasks of the enterprise. Expanding and improving forecasting problematic points and response task force objectives of development, degree of influence by clarifying inconsistencies.

\section{References}

Amendola, A., Braione, M., Candila, V., \& Storti, G. (2020). A Model Confidence Set approach to the combination of multivariate volatility forecasts. International Journal of Forecasting, 36(3), 873-891, ISSN 0169-2070, https://doi.org/10.1016/j.ijforecast.2019.10.001 Andriushchenko, K., Rudyk, V., Riabchenko, O., Kachynska, M., Marynenko, N., Shergina, L., Kovtun, V., Tepliuk, M., Zhemba, A., \& Kuchai, O. (2019). Processes of managing information infrastructure of a digital enterprise in the framework of the «Industry 4.0» concept. Eastern-European Journal of Enterprise Technologies, 1 (3 (97)), 60-72.

Dligach, A.A. (2016). System Reflexive Paradigm of Strategic Marketing. Proceedings of 10th IASTEM Inretnational Conference on Economics and Business Management (ICEBM). International Academy of Science, Technology, Engineering and Management (IASTEM), Institute of Research and Journals. Singapore, Bhubaneshwar, India, 5-9.

Fildes, R. \& Goodwin, P. (2020). Stability in the inefficient use of forecasting systems: A case study in a supply chain company, International Journal of Forecasting, ISSN 0169-2070, https://doi.org/10.1016/j.ijforecast.2020.11.004. Gonçalvesa, J.N.C., Cortez, P., Carvalhoa, M.S., \& Frazão, N.M. (2021). A multivariate approach for multi-step demand forecasting in assembly industries: Empirical evidence from an automotive supply chain, Decision Support Systems, 142, 113452, ISSN 0167-9236, https://doi.org/10.1016/j.dss.2020.113452.

Hu, Y., Li, J., Hong, M., Ren, J., Lin, R., Liu, Y., Liu, M., \& Man, Y. (2019). Short term electric load forecasting model and its verification for 


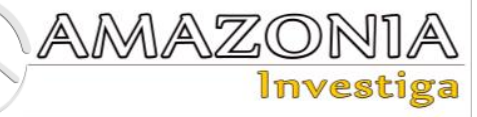

process industrial enterprises based on hybrid GA-PSO-BPNN algorithm A case study of papermaking process, Energy, Vol. 170, 12151227 , ISSN 0360-5442, https://doi.org/10.1016/j.energy.2018.12.208.

Kang., Y., Spiliotis, E., Petropoulos, F., Athiniotis, N., Li, F., \& Assimakopoulos, V. (2020). Déjà vu: A data-centric forecasting approach through time series cross-similarity, Journal of Business Research. ISSN 0148-2963, https://doi.org/10.1016/j.jbusres.2020.10.051.

Kuzior, A., Kwilinski, A., \& Hroznyi, I. (2021). The Factorial-Reflexive Approach to Diagnosing the Executors' and Contractors' Attitude to Achieving the Objectives by Energy Supplying Companies. Energies,

4(9), 2572, $\quad$ https://doi.org/10.3390/en1 4092572

Kwilinski, A., Dalevska, N., Kravchenko, S., Hroznyi, I., \& Kovalenko, I. (2019). Formation of the Entrepreneurship Model of E-Business in the Context of the Introduction of Information and Communication Technologies. Journal of Entrepreneurship Education, 22(SI1), 1-7.

Li, Ch., Tao, Y., Ao, W., Yang, S., \& Bai, Y. (2018). Improving forecasting accuracy of daily enterprise electricity consumption using a random forest based on ensemble empirical mode decomposition, Energy, 165, Part B, 12201227, ISSN 0360-5442, https://doi.org/10.1016/j.energy.2018.10.113.

Marinenko, N. (2016). Model for identifying processes that require immediate adaptation measures. Economics and management, 3 (71), 131-139. https://e-u.in.ua/journal/664.pdf

Nguyen, H.D., Tran, K.P., Thomassey, S., \& Hamad, M. (2021). Forecasting and Anomaly Detection approaches using LSTM and LSTM Autoencoder techniques with the applications in supply chain management. International Journal of Information Management, Vol. 57, 102282, ISSN

0268-4012, https://doi.org/10.1016/j.ijinfomgt.2020.102282.
Patomäki, H. (2017). Capitalism: Competition, Conflict, Crisis. Journal of Critical Realism, $16(5)$, 537-543. https://doi.org/10.1558/jocr.v1i2.175

Porter, M.E. (1987). From Competitive Advantage to Corporate Strategy. Harvard Business Review, 1987, 43-59.

Robert, K., \& Ola, L. (2020). Reflexive sensegiving: An open-ended process of influencing the sensemaking of others during organizational change. European Management Journal, 2020, ISSN 0263-2373, https://doi.org/10.1016/j.emj.2020.10.007.

Soros, G. (2013). Fallibility, Reflexivity, and the Human Uncertainty Principle. Journal of Economic Methodology, 20(4), 309-329. https://doi.org/10.1080/1350178X.2013.859415 Tarasova, H., Zaharov, S., Vereskun, M., \& Kolosok, V. (2019). Preventive anticrisis strategy for development of industrial enterprise. Independent Journal of Management \& Production, 10(5), 1405-1420, doi: 10.14807/ijmp.v10i5.890.

Wang, L., Jiang, W., Zhang, H., \& Lin, H. (2020). Leader information seeking, team performance and team innovation: Examining the roles of team reflexivity and cooperative outcome interdependence. Information Processing \& Management, 57(6), 102343, ISSN 0306-4573,

https://doi.org/10.1016/j.ipm.2020.102343.

Wang, R., \& Tan, J. (2021). Exploring the coupling and forecasting of financial development, technological innovation, and economic growth. Technological Forecasting and Social Change, Vol. 163, 120466, ISSN 0040-1625,

https://doi.org/10.1016/j.techfore.2020.120466. Zheng-Xin, W. (2013). An optimized Nash nonlinear grey Bernoulli model for forecasting the main economic indices of high technology enterprises in China. Computers \& Industrial Engineering, 64(3), 780-787, ISSN 0360-8352, https://doi.org/10.1016/j.cie.2012.12.010. 